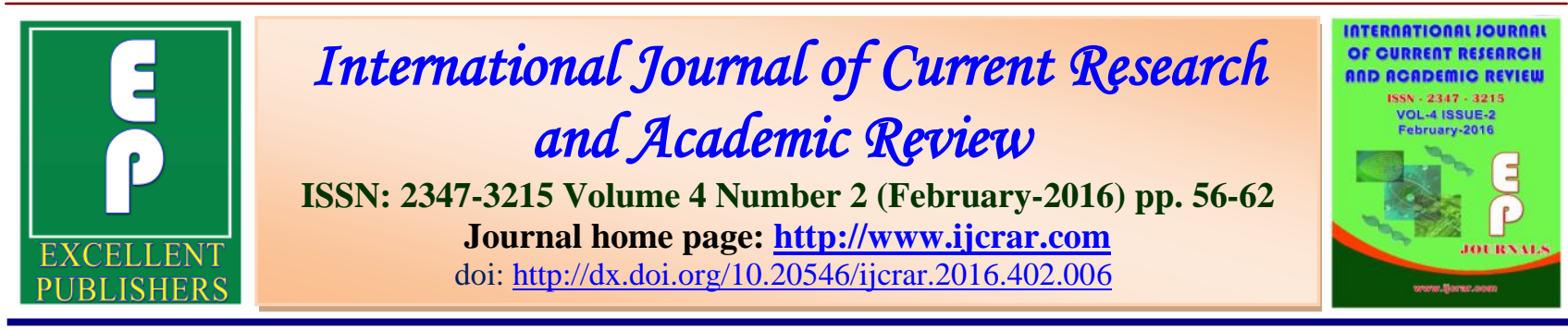

\title{
Immunohistochemical Based Detection of HPV in Gastric Cancer among Sudanese Patient
}

\section{Rua Abdel Mogeeb Omer Mohamed ${ }^{1}$, Ibrahim Bakhit Yousif Elemam ${ }^{2 *}$, Mahmud Mohammed Satti ${ }^{3}$ and Islam Bakri Mohammed Elhaj ${ }^{1}$}

${ }^{1}$ BS.c in medical laboratory sciences, AL- Neelain University, Sudan

${ }^{2}$ Department of Histopathology and Cytology, Faculty of Medical Laboratory Sciences-Shendi

University, Sudan

${ }^{3}$ B.Sc in Medical Laboratory Sciences, Sudan University for Sciences and Technology, Sudan

*Corresponding author

\begin{tabular}{|c|c|}
\hline KEYWORDS & A B S T R A C T \\
\hline $\begin{array}{l}\text { HPV, } \\
\text { Gastric Cancer, } \\
\text { Immuno- } \\
\text { histochemistry }\end{array}$ & $\begin{array}{l}\text { Screening for viruses is an essential step in the continuum of research that is } \\
\text { expected to lead to new treatment strategies in patients with virus-positive } \\
\text { tumors. This study aimed to demonstrate the presence of human papilloma } \\
\text { virus (HPV) in gastric tumors The study involved } 30 \text { formalin fixed paraffin } \\
\text { embedded blocks from patients with gastric tumors, collected during January } \\
2014 \text { and October2015.in histopathology departments of Omdurman teaching } \\
\text { hospital, Khartoum, Sudan. The presence of HPV was determined using } \\
\text { immunohistochemistry Among the } 30 \text { patients, } 20 \text { male }(66.7 \%) \text { and } 10 \\
\text { female ( } 33.3 \%) \text { with }(2: 1) \text { male: female ratio, only two samples }(6.7 \%) \text { were } \\
\text { positive for HPV, while } 28(93.3 \%) \text { were negative. the pathogenic causative } \\
\text { role of HPV infection in Sudanese patients with gastric cancer was not } \\
\text { established. }\end{array}$ \\
\hline
\end{tabular}

\section{Introduction}

Alimentary tract carcinoma is frequently occurred and have relatively high mortality rate. Recently, significant progress has been made in understanding the epidemiology, pathology and pathogenesis of alimentary tract carcinomas. Gastric cancer is the third leading cause of cancer death in both sexes worldwide (723000 deaths, $8.8 \%$ of the total) (1). The incidence rates are higher in men than in women and increased with age.
About $70 \%$ of cases occurred in developing countries, the highest estimated mortality rates are in Eastern Asia (24 per 100,000 in men, 9.8 per 100,000 in women), the lowest in Northern America (2.8 and 1.5, respectively). High mortality rates are also present in both sexes in Central and Eastern Europe, and in Central and South America. (2). 
In Sudan, the first official statistic from the Cancer Registry, 2009-2010 report gastric Cancer incidence (rate $=4.0$ per 100,000 ) . (3)

Dietary factors are major contributors to the etiology of this disease such as consumption of salty foods and $\mathrm{N}$-nitroso compounds with low intake of fresh fruits and vegetables increases the risk of gastric cancer, Salt-preserved foods and dietary nitrite found in preserved meats are potentially carcinogenic. Other risk factor include obesity, alcohol intake, and tobacco smoking, The role of chronic $\mathrm{H}$. pylori infection in the development of gastric Cancer is well establish, such that $\mathrm{H}$. pylori has been classified as a type I carcinogen by the International Agency for Research in Cancer (IARC). Epstein- Barr virus is another carcinogen has been linked to gastric cancer. (4)

Abundant evidence has demonstrated the oncogenic properties of HPV in studies on anal $(5,6)$, oral $(7,8)$ and pharyngeal cancers $(7,9)$, suggesting a possible role for the virus in the pathogenesis of cancer in other sections of the alimentary tract. The effect of HPV proteins E6 and E7 on the cell cycle is essential. Viral E6 and E7 oncoproteins that inactivate tumor suppressor proteins p53 and retinoblastoma are required for malignant transformation, the net effect of HPV E6 and E7 proteins is to block apoptosis and remove the restrains to cell proliferation (10). a few studies have focused on the role of HPV in the development of gastric cancer, with controversial result, some indicate the presence of HPV especially type16 (11), while other rule out the presence of HPV in gastric cancer (12), (13), (14).The present study was designed to study the presence of HPV by employing immunohistochemical methods in gastric cancer sections.

\section{Materials and Methods}

\section{Patients}

30 Paraffin embedded blocks of gastric biopsy samples were diagnosed as gastric carcinoma collected during January 2014 and October2015.in histopathology departments of Omdurman teaching hospital , Khartoum, Sudan .Tissue sectioning were performed in $(3 \mu \mathrm{m})$ thickness in order to perform $\mathrm{H} \& \mathrm{E}$ and immunohistochemical (IHC) staining. The presence of HPV was assessed based on IHC staining. Samples under study were histopathological diagnosed as gastric carcinoma. Patient identification data were retrieved from patients records data include age, sex and histological type of the tumor

\section{Immunohistochemistry}

The immunohistochemical procedure was done as follows: one section $(3 \mu \mathrm{m})$ from formalin-fixed, paraffin-embedded tumors was cut and mounted onto salinized slides (Thermo). Following deparaffinization in xylene, slides was rehydrated through a graded series of alcohol and was placed in distilled water. Samples were steamed for antigen retrieval for HPV using high $\mathrm{PH}$ (9) by water bath at 95c. Endogenous peroxidase activity was blocked with $3 \%$ hydrogen peroxide and methanol for $10 \mathrm{~min}$, and then Slides was incubated with 100-200 $\mu \mathrm{l}$ of primary antibodies for $20 \mathrm{~min}$ at room temperature in a moisture chamber. After washing with PBS for $3 \mathrm{~min}$, binding of antibodies will be detected by incubating for 20 minutes with dextran labeled polymer ((Thermo-ultra vision). Finally, the sections washed in three changes of PBS, followed by adding 3,3 diaminobenzidine tetra hydrochloride (DAB) as a chromogen to produce the characteristic brown stain for the visualization of the antibody/enzyme 
complex for up to $5 \mathrm{~min}$. Slides was counterstained with haematoxylin. Each slide was evaluated with investigator then the results were confirmed by consultant histopathologist.

\section{Statistical Analyzes}

Data were analyzed using SPSS 20 software; numerical data was analyzed using the mean as an indicator of location and the standard deviation (SD) for measuring dispersion. For nominal data description of frequencies in the form of percentage was the analytical method used. Correlate analyses were done by using the chi-squared tests, the $\mathrm{P}$ value extracted as an indicator of significance. $\mathrm{P}<$ 0.05

\section{Result and Discussion}

\section{Samples Recruitment and Histological Types}

Thirty cases of gastric cancer were included in this study. The frequency of histological types was as follow; 12(40\%) cases of adenocarcinoma, $11(36.7 \%)$ cases of gastrointestinal stromal tumor, $4(13.3 \%)$ cases of squamous cell carcinoma and $3(10 \%)$ cases of gastric non-Hodgkin lymphoma (figure 1). There was no statistical significant correlation between histological types of the gastric cancer and patient's age and gender (table $2 \& 3$ ).

\section{Patient Age}

The patients' age ranged between 15 and 80 years with mean of age about 55.8 years.

\section{HPV Immunostain Pattern}

The HPV showed positive staining reaction in one case of adenocarcinoma and one case of non-Hodgkin lymphoma. There was no significant correlation between histological types of the gastric cancer and HPV presence (P value was 0.19), table -1.

Dietary habits and lifestyle factors are considered as a main risk of developing gastric cancer (GAC), in addition to the infection with $H$. pylori or EBV (1-15). EBV has been accepted as an infective agent of gastric and colorectal carcinomas. Nearly $10 \%$ of all gastric cancers have been found to be associated with EBV (16-17). Some of the published studies have ruled out presence of HPV in stomach cancer (18-19), whereas others indicated role of HPV 16 in gastric cancer (11-).However, the role of HPV in GAC has not been yet extensively studied. Therefore, the current study aimed for futher clarification of the association between HPV and GAC in Sudan .

Human papilloma viruses (HPVs) was the first known human tumour virus with over 200 types classified into 16 genera ,they most commonly known for their benign and neoplastic diseases of the anogenital tract(20). Abundant evidence has demonstrated the oncogenic properties of HPV in studies on anal(5),oral (21),pharyngeal (9), colorectal (22) and esophageal cancers (23), suggesting a possible role for the virus in the pathogenesis of other cancers of the alimentary tract.

The present study include thirty cases of gastric cancers. The patient's age ranged between 15 and 80 years with mean of age about 55.8 years, and this seems to be similar to the age range in the study of Guamer et al.(24)

Our study demonstrated that the HPV immunostain positive rate was $(6.7 \%)$ in gastric cancer tissues. These findings address the role of HPV in pathogenesis of gastric cancer in Sudanese patients. 
Int.J.Curr.Res.Aca.Rev.2016; 4(2): 56-62

Table.1 Relation between Tumors Type and HPV Presence

\begin{tabular}{|c|c|c|c|c|}
\hline \multirow[t]{2}{*}{ Type of Tumor } & \multicolumn{2}{|c|}{$\begin{array}{l}\text { HPV immunostain } \\
\text { reaction }\end{array}$} & \multirow[t]{2}{*}{ Total } & \multirow[t]{2}{*}{$\begin{array}{l}\mathrm{P} \\
\text { value }\end{array}$} \\
\hline & Positive & Negative & & \\
\hline Adenocarcinoma & 1 & 11 & 12 & \multirow{5}{*}{0.19} \\
\hline $\begin{array}{l}\text { gastrointestinal } \\
\text { stromal tumor }\end{array}$ & 0 & 11 & 11 & \\
\hline $\begin{array}{ll}\text { Squamous cell } \\
\text { carcinoma }\end{array}$ & 0 & 4 & 4 & \\
\hline $\begin{array}{l}\text { Non Hodgkin } \\
\text { lymphoma }\end{array}$ & 1 & 2 & 3 & \\
\hline Total & 8 & 28 & 30 & \\
\hline
\end{tabular}

Table.2 Correlation between the Age Group and Type of Tumor

\begin{tabular}{|c|c|c|c|c|c|c|c|c|c|}
\hline \multirow[t]{2}{*}{ Type of Tumor } & \multicolumn{7}{|c|}{ Age group } & \multirow[t]{2}{*}{ Total } & \multirow[t]{2}{*}{$\mathrm{P}$ value } \\
\hline & $10-20$ & $21-30$ & $31-40$ & $41-50$ & $51-60$ & $61-70$ & $71-80$ & & \\
\hline Adenocarcinoma & 0 & 0 & 1 & 5 & 3 & 1 & 2 & 12 & \\
\hline $\begin{array}{l}\text { gastrointestinal } \\
\text { stromal tumor }\end{array}$ & 0 & 1 & 0 & 0 & 2 & 0 & 1 & 4 & \\
\hline $\begin{array}{l}\text { Squamous cell } \\
\text { carcinoma }\end{array}$ & 1 & 0 & 1 & 1 & 1 & 2 & 5 & 11 & \\
\hline $\begin{array}{l}\text { Non Hodgkin } \\
\text { lymphoma }\end{array}$ & 0 & 1 & 1 & 0 & 1 & 0 & 0 & 3 & \\
\hline Total & 1 & 2 & 3 & 6 & 7 & 3 & 8 & 30 & 0.235 \\
\hline
\end{tabular}

Table.3 Correlation between the Sex Group and Type of Tumor

\begin{tabular}{|l|c|c|c|c|}
\hline \multirow{2}{*}{ Type of Tumor } & \multicolumn{2}{|c|}{ Gender } & \multirow{2}{*}{ P.value } \\
\cline { 2 - 4 } & Male & Female & Total & \\
\hline Adenocarcinoma & 8 & 4 & 12 & \\
\hline $\begin{array}{l}\text { gastrointestinal } \\
\text { stromal tumor }\end{array}$ & 4 & 0 & 4 & \multirow{2}{*}{0.126} \\
\hline $\begin{array}{l}\text { Squamous cell } \\
\text { carcinoma }\end{array}$ & 5 & 6 & 11 & \\
\hline $\begin{array}{l}\text { Non Hodgkin } \\
\text { lymphoma }\end{array}$ & 3 & 0 & 3 & \\
\hline Total & 20 & 10 & 30 & \\
\hline
\end{tabular}


Figure.1 The Frequency of Different Histological Types of Gastric Cancer

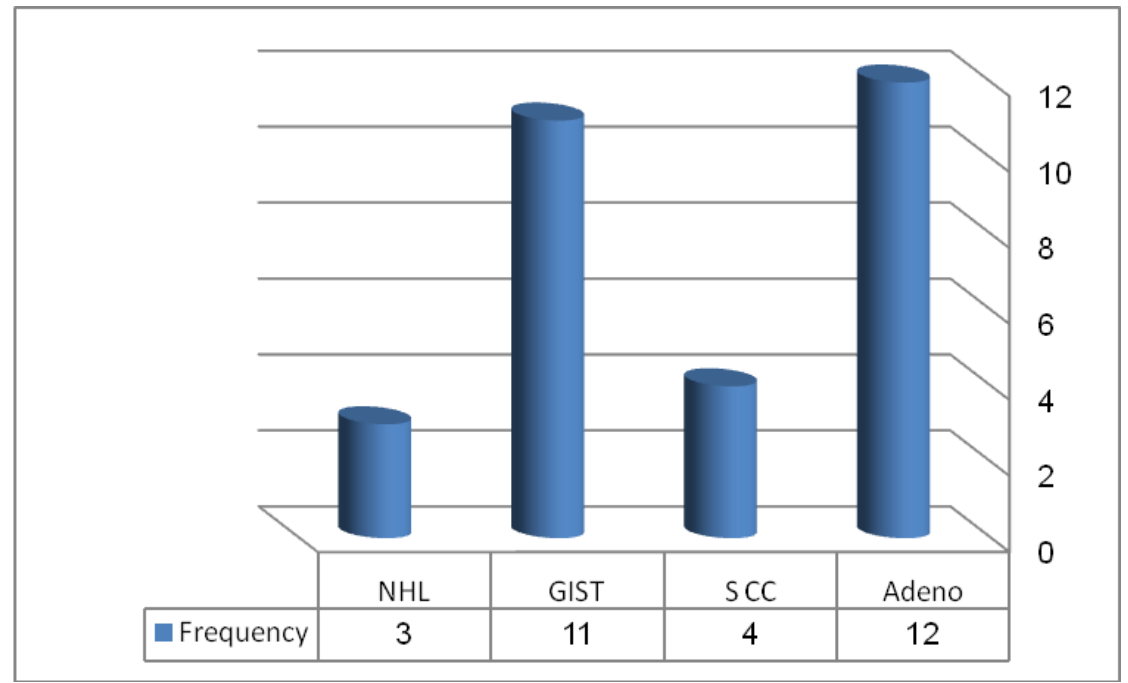

The same finding was obtained in other studies by Kamangar et al (20), who published a co- hort study which used a serologic test for the identification of HPV 16, HPV 18 and HPV 73 in China and found no significant association. Saegusa et al (25) investigated the occurrence of HPV in GC in Japan using PCR for gene L1 or E6- E7, but the entire series of patients was negative. Turner et al (26) evaluated the incidence of HPV in esophagus cancer, using PCR to test the L1 and E7. Only 1 sample was positive, and did not demonstrate a significant presence of HPV infection in patients with GC ( $\mathrm{p}=0.077)$.

Another study by Yuan et al. (13), a total of 98 patients were involved in that study. PCR analyses were carried out to determine the presence of EBV and HPV DNA material, neither EBV nor HPV DNA was detected in any of the patients' tissue, including gastric carcinoma cells, adjacent dysplastic epithelium, surrounding, lymphocytes and paired normal gastric mucosa.

On the other hand there are many other studies highlighting the role of HPV in gastric cancer. The study performed by
Tian-You Ma et al (27) found a significant increase in the prevalence of HPV in GC cells when compared to the nearby gastric mucosa without cancer. Xu et al (11) studied patients in China by in situ hybridization to detect gene expression of HPV E6 $16 \mathrm{~m}$ RNA and concluded that HPV could be a factor in the etiology and development of GC.

\section{Conclusion}

Infectious agents such as HPV are suspected to play causal roles in various human malignancies. However, this study did not confirm the role of HPV in the pathogenesis of gastric cancer.

\section{References}

1. International Agency for Research on Cancer. GLOBOCAN 2012: estimated cancer incidence, mortality and prevalence worldwide in 2012 Stomach Cancer, 2014-01, cited 201401-20.

2. Siegel RL, Miller KD, Jemal A. Cancer statistics, 2015. CA Cancer J Clin. 2015;65(1):5-29. 
3. Saeed IE, Weng HY, Mohamed KH, Mohammed SI. Cancer incidence in Khartoum, Sudan: first results from the Cancer Registry, 2009-2010. Cancer Med. 2014;3(4):1075-84.

4. Crew KD, Neugut AI. Epidemiology of gastric cancer. World J Gastroenterol. 2006;12(3):354-62.

5. Steenbergen RD, de Wilde J, Wilting SM, Brink AA, Snijders PJ, Meijer CJ. HPV-mediated transformation of the anogenital tract. J Clin Virol 2005; 32 Suppl 1: S25-S33

6. Gervaz P, Hirschel B, Morel P. Molecular biology of squamous cell carcinoma of the anus. Br J Surg 2006; 93: $531-538$

7. Śnietura M, Jaworska M, Pigłowski W, Goraj-Zając A, Woźniak G, Lange D. High-risk HPV DNA status and p16 (INK4a) expression as prognostic markers in patients with squamous cell cancer of oral cavity and oropharynx. Pol J Pathol 2010; 61: 133-139

8. Herrero R, Castellsagué X, Pawlita M, Lissowska J, Kee F, Balaram P, Rajkumar T, Sridhar H, Rose B, Pintos J, Fernández L, Idris A, Sánchez MJ, Nieto A, Talamini R, Tavani A, Bosch FX, Reidel U, Snijders PJ, Meijer CJ, Viscidi R, Muñoz N, Franceschi S. Human papillomavirus and oral cancer: the International Agency for Research on Cancer multicenter study. J Natl Cancer Inst 2003; 95: 1772-1783

9. Snietura M, Piglowski W, Jaworska M, Mucha-Malecka A, Wozniak G, Lange D, Suwinski R. Impact of HPV infection on the clinical outcome of $\mathrm{p}$ CAIR trial in head and neck cancer. Eur Arch Otorhinolaryngol 2011; 268: 721726

10. Robbins and Cotran pathologic basis of diseaseVinay Kumar - Abul Abbas Nelson Fausto - Stanley Robbins -
Ramzi Cotran - Elsevier Saunders 2005.

11. Xu WG, Zhang LJ, Lu ZM, Li JY, Ke $\mathrm{Y}, \mathrm{Xu} \mathrm{GW}$. (Detection of human papillomavirus type $16 \mathrm{E} 6 \mathrm{mRNA}$ in carcinomas of upper digestive tract). Zhonghua Yi Xue Za Zhi. 2003;83(21):1910-4.

12. Snietura M, Waniczek D, Piglowski W, et al. Potential role of human papilloma virus in the pathogenesis of gastric cancer. World J Gastroenterol. 2014;20(21):6632-7.

13. Yuan XY, Wang MY, Wang XY, Chang AY, Li J. Non-detection of Epstein-Barr virus and Human Papillomavirus in a region of high gastric cancer risk indicates a lack of a role for these viruses in gastric carcinomas. Genet Mol Biol. 2013;36(2):183-4.

14. Cândido AC, De lima filho JL, Martins DB, Mendes CM, Vieira JR, Ferraz AA. Association of human papillomavirus genomic sequences by polymerase chain reaction in gastric carcinomas in Brazil. Anal Quant Cytopathol Histpathol. 2013;35(1):1-6.

15. Sekine K, Nagata N. Synchronous gastric cancer presenting different pathological features depending on the involvement of Epstein-Barr virus infection. Clin Res Hepatol Gastroenterol 2013; 37: 111-112

16. Uozaki H, Fukayama M: Epstein-Barr virus and gastric carcinoma-viral carcinogenesis through epigenetic mechanisms. Int $\mathbf{J}$ Clin Exp Pathol 2008, 1(3):198-216.

17. Ryan JL, Jones RJ, Kenney SC, Rivenbark AG, Tang W, Knight ER, Coleman WB, Gulley ML: Epstein-Barr virus-specific methylation of human genes in gastric cancer cells. Infect Agent Cancer 2010, 5:27. 
18. Strickler HD, Schiffman MH, Shah KV, Rabkin CS, Schiller JT, Wacholder S, et al. A survey of human papillomavirus 16 antibodies in patients with epithelial cancers. Eur J Cancer Prev 1998; 7 : 305-13.

19. Kamangar F, Qiao YL, Schiller JT, Dawsey SM, Fears T, Sun XD, et al. Human papillomavirus serology and the risk of esophageal and gastric cancers: results from a cohort in a high-risk region in China. Int $\mathrm{J}$ Cancer 2006; 119 : 579-84.

20. Cubie HA. Diseases associated with human papillomavirus infection. Virology. 2013;445(1-2):21-34.

21. SYRJÄNEN, K. et al. Morphological and immunohistochemical evidence suggesting human papillomavirus (HPV) involvement in oral squamous cell carcinogenesis. Int $\mathbf{J}$ Oral Surg 1983, v. 12, n. 6, p. 418-24.

22. Damin DC, Ziegelmann PK, Damin AP. Human papillomavirus infection and colorectal cancer risk: a meta-analysis. Colorectal Dis. 2013;15(8):e420-8.

23. de Villiers EM, Lavergne D, Chang F, Syrjanen K, Tosi P, Cintorino M. An interlaboratory study to determine the presence of human papillomavirus DNA in esophageal carcinoma from China. Int J Cancer, 1999 .81:225-8.
24. Guamer, J., Mohar, A., Parsonnet, J., Halperin, D. The association of h.pylori with gastric cancer and preneoplastic gastric lesions in Mexico. International Agency for Research on Cance 1993r,71: 279-301.

25. Saegusa M, Hashimura M, Takano Y, Ohbu M, Okayasu I: Absence of human papillomavirus genomic sequences detected by the polymerase chain reaction in oesophageal and gastric carcinomas in Japan. Mol Pathol 1997;50:101-104

26. Turner JR, Shen LH, Crum CP, Dean PJ, Odze RD: Low prevalence of human papillomavirus infection in esophageal squamous cell carcinomas from North America: Analysis by a highly sensitive and specific polymerase chain reactionbased approach. Hum Pathol 1997;28:174-178.

27. Ma T, Liu W, Chu Y, Jiang X, Na Y, Zhang M, Zheng J: Detection of human papillomavirus type 16 DNA in formalin-fixed, paraffin-embedded tissue specimens of gastric carcinoma. Eur J Gastroenterol Hepatol 2007;19:1090-1096.

\section{How to cite this article:}

Rua Abdel Mogeeb Omer Mohamed, Ibrahim Bakhit Yousif Elemam, Mahmud Mohammed Satti and Islam Bakri Mohammed Elhaj. 2016. Immunohistochemical Based Detection of HPV in Gastric Cancer among Sudanese Patient. Int.J.Curr.Res.Aca.Rev. 4(2): 56-62. doi: http://dx.doi.org/10.20546/ijcrar.2016.402.006 